\title{
Hubungan Pengetahuan Ibu Primigravida dengan Kesiapan Ibu dalam Menghadapi Persalinan di Wilayah Kerja Puskesmas Deket Kabupaten Lamongan
}

\author{
Husnul Muthoharoh ${ }^{1}$ \\ ${ }^{1}$ Program Studi Diploma III Kebidanan Universitas Islam Lamongan \\ Email : ques.muth@gmail.com
}

Received 2 May 2018; Accepted 8 May 2018; Published 15 May 2018

\begin{abstract}
Primigravida mothers are first and pregnant mothers who have not had the experience of labor, so labor is important to know the knowledge to deal with the readiness of good delivery. Preliminary survey results from 10 primigravida mother know $70 \%$ among others less readiness to face delivery. Lack of readiness can result in delayed deliveries mother came to the health service or that known by the term 3T. The research aims to determine the relationship of knowledge primigravida mothers with maternal readiness in the face of labor in working area Deket Community Health Center Lamongan District. Observational study design using analytical and cross-sectional approach. Independent variable is the knowledge of primigravida mothers about childbirth, the dependent variable is the readiness of the mother in the face of labor. The study population is the mother of three in trimester primigravidae in working area Deket Community Health Center Lamongan District. Sample as many as 28 people were taken by total sampling. Research instrument was a questionnaire. The data in the test with a contingency coefficient with significance $\alpha: 0.05$. The Result contingency coefficient value 0.034 means $\mathrm{p}<\alpha(0.034<0.05)$. From the above research in getting the conclusion $\mathrm{H}_{0}$ is rejected it means there is a relationship between knowledge of primigravida mothers with maternal readiness in the face of labor. Midwives are expected to come into play as well as provide good information about labor for primigravidae women in the presence of good care Antenatal Care during pregnancy for mothers primigravidae so with the knowledge of good birth, mothers can have a good labor readiness.
\end{abstract}

Keywords : Birth preparedness, knowledge, primigravida mother.

Copyright $\odot 2018$ STIKes Surya Mitra Husada

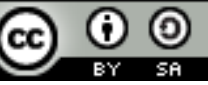

This is an open-acces article distributed under the terms of the Creative Commons Attribution-ShareAlike 4.0 International License. 


\section{PENDAHULUAN}

Kesiapan persalinan menjadi salah satu tolak ukur dalam keberhasilan proses persalinan. Seorang ibu primigravida yang belum memahami tentang persalinan sering kali mengalami kesulitan dalam mempersiapkan persalinannya. Oleh karena itu, saat kehamilan berlangsung ibu sudah harus diberi pengetahuan tentang persalinan dan kesiapan apa saja yang dibutuhkan. Kurangnya persiapan persalinan disebabkan karena kurangnya pengetahuan ibu, rendahnya tingkat pendidikan, sosial budaya, sosial ekonomi (Geniofam, 2010).

Banyak hal yang harus dipersiapkan menjelang kelahiran bayi, mulai dari persiapan mental, fisik maupun finansial atau keuangan. Kesiapan metal dan fisik ibu dapat dibentuk selama kehamilan dengan konseling dari bidan dan motivasi diri untuk segera melihat bayinya tetapi persiapan finansial sering kali menjadi ganjalan ibu dalam persalinan. Rendahnya tingkat perekonomian menjadi salah satu faktor keluarga memilih penolong persalinan dan tidak bersedia dilakukan rujukan segera saat terjadi komplikasi. Faktor ekonomi bukan hanya berpengaruh bagi lancar atau tidaknya persalinan tetapi juga dapat mengakibatkan meningkatnya Angka Kematian Ibu (AKI) (Manuaba, 2007).

Data Kementerian Kesehatan menunjukkan angka kematian bayi dan ibu saat melahirkan mengalami penurunan sejak 2015 hingga semester pertama 2017. Jumlah kasus kematian bayi turun dari 33.278 kasus pada 2015 menjadi 32.007 kasus pada 2016. Sementara hingga pertengahan tahun atau semester satu 2017 tercatat sebanyak 10.294 kasus kematian bayi. Demikian pula dengan angka kematian ibu saat melahirkan turun dari 4.999 kasus pada 2015 menjadi 4.912 kasus di tahun 2016. Sementara hingga semester satu di tahun 2017 terjadi 1.712 kasus kematian ibu saat proses persalinan.

Berdasarkan survey awal yang dilakukan oleh peneliti, jumlah keseluruhan ibu hamil yang memeriksakan kehamilan di puskesmas Deket Kabupaten Lamongan pada bulan September 2017 terdapat 10 primigravida yang memeriksakan kehamilan dan $70 \%$ diantaranya kurang mengetahui kesiapan menghadapi persalinan.

Penyebab terlambatnya ibu ke tempat pelayanan kesehatan karena kurangnya pengetahuan ibu hamil tentang tanda-tanda persalinan dan kurang siapnya ibu primigravida menghadapi persalinan. Akibatnya ibu primigravida mengalami kesulitan dalam menghadapi persalinannya. Tanda-tanda persalinan setiap wanita sama diantaranya yaitu kenceng-kenceng yang semakin lama semakin sering dan sakit, keluar lendir darah, pecahnya ketuban, walaupun dalam proses persalinannya berbeda-beda. Maka dengan adanya kesiapan persalinan dan pengetahuan tentang tanda-tanda persalinan ibu hamil terutama bagi ibu hamil primigravida trimester III akan segera datang ke bidan atau rumah bersalin dengan persiapan yang dimiliki (Saleha, 2009). Kesiapan persalinan berperan penting untuk mengurangi angka kematian ibu yang disebabkan karena adanya istilah terlambat yaitu terlambat mengambil keputusan dalam memberi pertolongan pada ibu hamil dan melahirkan, terlambat membawa ketempat pelayanan kesehatan dan terlambatnya tenaga medis memberi pertolongan (Prawirohardjo, 2007).

Bidan sebagai tenaga kesehatan harus ikut mendukung upaya mempercepat penurunan AKI yaitu diperlukan suatu usaha yang salah satunya adalah pelayanan antenatal atau Antenatal Care (ANC) dan diadakannya kelas ibu bagi ibu hamil yang akan menghadapi persalinan. Pelayanan antenatal merupakan pilar kedua dalam Safe Motherhood yang merupakan sarana agar ibu lebih siap menghadapi persalinan. Ketidaksiapan ibu dalam menghadapi persalinan menjadi salah satu faktor penyebab tingginya AKI. Bila saat persalinan ditemukan adanya komplikasi obstetri dan ibu tidak mengerti tentang persiapan yang dibutuhkan menjelang persalinan, maka ibu tidak mendapatkan pelayanan yang sesuai dan tepat waktu. Selain itu, pemerintah juga harus ikut berperan dalam meningkatkan pelayanan kesehatan bagi masyarakat dengan ekonomi kurang mampu.

Berdasarkan latar belakang diatas oleh karena itu penulis ingin melakukan penelitian dengan judul "Hubungan Pengetahuan Ibu Primigravida tentang Persalinan Dengan Kesiapan Ibu Dalam Menghadapi Persalinan 


\section{BAHAN DAN METODE}

Desain penelitian yang digunakan dalam penelitian ini adalah observasional analitik dengan pendekatan cross sectional. Variabel independen dalam penelitian ini adalah pengetahuan ibu primigravida tentang persalinan dan variabel dependen dalam penelitian ini adalah kesiapan ibu dalam menghadapi persalinan. Populasi pada penelitian ini adalah ibu primigravida trimester 3 di wilayah kerja puskesmas Deket Kabupaten Lamongan pada bulan Oktober sampai dengan Desember 2017. Teknik sampling yang digunakan dalam penelitian ini adalah probability, yaitu jenis total sampling. Sampel dalam penelitian ini adalah ibu primigravida trimester tiga di wilayah kerja puskesmas Deket Kabupaten Lamongan sebanyak 28 responden.

\section{HASIL}

1. Usia

Berdasarkan penelitian di wilayah kerja puskesmas Deket Kabupaten Lamongan diketahui bahwa 28 Ibu Primigravida berusia antara 20-35 tahun.

\section{Pendidikan}

Tabel 1 Distribusi Ibu Primigravida berdasarkan pendidikan ibu primigravida di wilayah kerja puskesmas Deket Kabupaten Lamongan tahun 2017.

\begin{tabular}{clcc}
\hline No & Pendidikan & Jumlah & Presentase (\%) \\
\hline 1 & Tidak sekolah & 0 & 0 \\
2 & SD & 4 & 14,3 \\
3 & SMP & 12 & 42,9 \\
4 & SMA & 9 & 32,1 \\
5 & PT & 3 & 10,7 \\
\hline \multicolumn{2}{r}{ Jumlah } & 28 & 100 \\
\hline
\end{tabular}

Dari Tabel 1 di atas didapatkan data bahwa hampir sebagian Ibu Primigravida berpendidikan SMP yakni 12 Ibu Primigravida $(42,9 \%)$.

\section{Pekerjaan}

Tabel 2 Distribusi Ibu Primigravida berdasarkan pekerjaan ibu primigravida di wilayah kerja puskesmas Deket Kabupaten Lamongan tahun 2017.

\begin{tabular}{llcc}
\hline No & Pendidikan & Jumlah & Presentase (\%) \\
\hline 1 & IRT/Tidak bekerja & 19 & 67,9 \\
2 & Buruh tani/petani & 4 & 14,3 \\
3 & Swasta/Wiraswasta & 5 & 17,9 \\
4 & PNS/TNI/POLRI & 0 & 0 \\
\hline \multicolumn{2}{c}{ Jumlah } & 28 & 100 \\
\hline
\end{tabular}

Dari Tabel 2 di atas didapatkan data bahwa hampir seluruh Ibu Primigravida tidak bekerja atau sebagai IRT yaitu 19 (67,9\%) Ibu Primigravida. 


\section{Pengetahuan ibu primigravida tentang persalinan}

Tabel 3 Distribusi Ibu Primigravida Berdasarkan Pengetahuan Ibu Primigravida Tentang Persalinan di di wilayah kerja puskesmas Deket Kabupaten Lamongan tahun 2017.

\begin{tabular}{cllcc}
\hline No & Pengetahuan Ibu Primigravida Tentang Persalinan & Frekuensi & Presentase (\%) \\
\hline 1 & Baik & 7 & 25,0 \\
2 & Cukup & 9 & 32,1 \\
3 & Kurang & 12 & 46,9 \\
\hline & & 28 & 100 \\
\hline
\end{tabular}

Dari tabel 3 di atas didapatkan data bahwa hampir sebagian Ibu Primigravida memiliki pengetahuan yang kurang tentang persalinan yaitu 12 Ibu Primigravida $(46,9 \%)$.

\section{Kesiapan dalam Menghadapi Persalinan}

Tabel 4 Distribusi Ibu Primigravida berdasarkan Kesiapan Dalam Menghadapi Persalinan di wilayah kerja puskesmas Deket Kabupaten Lamongan tahun 2017.

\begin{tabular}{clccc}
\hline No & & Kesiapan Dalam Menghadapi Persalinan & Frekuensi & Presentase (\%) \\
\hline 1 & Siap & & 4 & 14,3 \\
2 & Tidak siap & Jumlah & 24 & 85,7 \\
\hline & & 28 & 100 \\
\hline
\end{tabular}

Dari Tabel 4 diatas didapatkan data bahwa hampir seluruh Ibu Primigravida tidak memiliki kesiapan dalam menghadapi persalinan yakni 24 Ibu Primigravida (85,7\%).

6. Tabel Silang Antara Pengetahuan Ibu Primigravida dengan Kesiapan Ibu Dalam Menghadapi Persalinan.

Tabel 5 Tabel Silang antara Pengetahuan Ibu Primigravida dengan Kesiapan Ibu Dalam Menghadapi Persalinan di wilayah kerja puskesmas Deket Kabupaten Lamongan tahun 2017.

\begin{tabular}{ccccc}
\hline \multirow{2}{*}{ No } & \multirow{2}{*}{ Pengetahuan } & \multicolumn{2}{c}{ Kesiapan Ibu Dalam Menghadapi Persalinan } & \multirow{2}{*}{ Jumlah } \\
\cline { 3 - 4 } & & Siap & Tidak Siap & \\
\hline 1 & Baik & $3(42,9 \%)$ & $4(57,1 \%)$ & $7(100 \%)$ \\
2 & Cukup & $1(14,3 \%)$ & $8(85,7 \%)$ & $9(100 \%)$ \\
3 & Kurang & $0(0,00 \%)$ & $12(100 \%)$ & $12(100 \%)$ \\
\hline & Jumlah & $4(15,4 \%)$ & $24(84,6 \%)$ & $28(100 \%)$ \\
\hline
\end{tabular}

Dari Tabel 5 menunjukkan bahwa dari 12 Ibu Primigravida yang memiliki pengetahuan kurang tentang persalinan seluruhnya tidak memiliki kesiapan dalam menghadapi persalinan.

Setelah dianalisa dengan program SPSS Versi 16.0 for Windows yang menggunakan uji koefisien kontingensi di dapatkan hasil nilai koefisien kontingensi 0,034 . Karena nilai $\alpha$ : 0,05 dan nilai dari koefisien kontingensi adalah 0,034 berarti $\mathrm{p}>\alpha(0,05>0,034)$, artinya $\mathrm{H}_{0}$ ditolak artinya ada hubungan pengetahuan ibu primigravida dengan kesiapan ibu dalam menghadapi persalinan. 


\section{PEMBAHASAN}

\section{Pengetahuan Ibu Primigravida tentang persalinan.}

Dari tabel 3 menunjukkan bahwa hampir sebagian ibu primigravida (46,9\%) pengetahuannya masih kurang tentang persalinan. Hal ini dipengaruhi oleh pendidikan ibu primigravida di wilayah kerja puskesmas Deket Kabupaten Lamongan yang mayoritas memiliki pendidikan tingkat dasar. Menurut Kuncoroningrat yang dikutip oleh Nursalam (2003) bahwa semakin tinggi tingkat pendidikan seseorang, makin mudah menerima informasi sehingga makin banyak pula pengetahuan yang dimiliki sebaliknya pendidikan yang kurang akan menghambat perkembangan sikap seseorang terhadap nilai-nilai yang baru diperkenalkan.

Ibu primigravida adalah ibu yang pertama kali hamil dan tidak memiliki pengalaman kehamilan maupun persalinan. Oleh karena itu, ibu membutuhkan banyak informasi mengenai kehamilan dan persalinan sehingga bisa menjalani kehamilan dan persalinannya dengan baik. Seseorang tidak akan bisa mengetahui informasi tanpa adanya sumber informasi atau media.

Media informasi saat ini sangat beragam seperti buku, majalah, koran, televisi, radio dan masih banyak lagi. Hal itu bisa memudahkan seorang ibu primigravida memperoleh informasi tentang persalinan, sehingga pengetahuan yang ibu dapat tidak hanya berasal dari bidan. Menurut Notoatmodjo (2005) bahwa kemudahan untuk memperoleh suatu informasi dapat membantu mempercepat seseorang untuk memperoleh pengetahuan yang baru. Akan tetapi pengetahuan itu sendiri tidak hanya dipengaruhi oleh banyaknya informasi yang didapat tapi banyak faktor yang mempengaruhi seseorang untuk mendapatkan informasi yang baik. Seperti yang dikemukakan oleh Mubarak (2007) bahwa banyak faktor yang mempengaruhi pengetahuan antara lain pendidikan, pekerjaan, umur, minat, pengalaman, faktor lingkungan, informasi, status ekonomi dan hubungan sosial.

Berdasarkan penelitian di wilayah kerja puskesmas Deket Kabupaten Lamongan sebagian besar ibu primigravida berpendidikan SMP (42,9\%) dan tidak dapat dipungkiri bahwa dengan pendidikan yang rendah makin sulit bagi ibu primigravida untuk menerima informasi sehingga makin terbatas pengetahuan tentang persalinan yang dimiliki dan makin tinggi pendidikan sesorang semakin mudah pula mereka menerima informasi dan pada akhirnya makin banyak pula pengetahuan yang dimilikinya.

\section{Kesiapan Ibu Primigravida dalam Menghadapi Persalinan}

Pada tabel 4 menunjukkan bahwa sebagian besar ibu primigravida tidak memiliki kesiapan dalam menghadapi persalinan $(85,7 \%)$.

Kesiapan persalinan adalah hal yang penting di ketahui bagi ibu primigravida karena ibu primigravida tidak memiliki pengalaman persalinan. Pengetahuan yang baik dapat membantu ibu primigravida meningkatkan kesiapan dalam menghadapi persalinan. Akan tetapi kesiapan persalinan tidak hanya dipengaruhi oleh banyaknya pengetahuan tetapi dukungan dan motivasi dari orang-orang terdekat juga dapat meningkatkan kesiapan ibu dalam menghadapi persalinan. Selain motivasi yang diberikan oleh bidan pada saat antenatal care (ANC), keluarga juga dapat ikut berperan menjaga kesehatan fisik dan memberikan dukungan untuk memperkuat mental ibu dalam menghadapi persalinan. Kesiapan persalinan yang baik membantu ibu menjalani persalinan dengan lebih mudah

\section{Hubungan Pengetahuan Ibu Primigravida tentang Persalinan Dengan Kesiapan Ibu Dalam Menghadapi Persalinan.}

Dari tabel 5 hasil uji cross sectional menunjukkan ibu primigravida yang memiliki pengetahuan yang kurang $(0 \%)$ juga tidak memiliki kesiapan yang baik dalam menghadapi 
persalinan (100\%). Menurut Notoatmodjo (2005) perilaku yang didasari pengetahuan akan lebih langgeng dari pada perilaku yang tidak didasari oleh pengetahuan. Begitu juga dengan pengetahuan ibu primigravida tentang persalinan yang dapat meningkatkan kesiapan ibu dalam menghadapi persalinan.

Kesiapan persalinan menjadi salah satu tolok ukur dalam keberhasilan proses persalinan. Seorang ibu primigravida yang belum memahami tentang persalinan sering kali mengalami kesulitan dalam mempersiapkan persalinannya. Oleh karena itu saat kehamilan berlangsung ibu sudah harus memiliki pengetahuan tentang persalinan dan kesiapan apa saja yang dibutuhkan. Kurangnya persiapan persalinan disebabkan karena kurangnya pengetahuan ibu, rendahnya tingkat pendidikan, sosial budaya, sosial ekonomi.

Pengetahuan merupakan domain yang sangat penting untuk terbentuknya tindakan seseorang. Dan tindakan maka akan timbul suatu kesadaran (awareness), tertarik (interest), penilaian (evaluation), mencoba (trial), dan adaptasi (adaption) sehingga akhirnya orang itu mampu mengaplikasikan pengetahuan yang didapat dalam kehidupan yang nyata (Notoatmodjo, 2005).

Perubahan perilaku seseorang diawali dengan pengetahuan. Sedangkan pengetahuan dipengaruhi oleh pendidikan. Sesuai pendapat Latipun (2001) bahwa pendidikan seseorang mempengaruhi cara pandang terhadap lingkungannya. Karena itu berbeda pengetahuan seseorang yang berpendidikan tinggi dibandingkan dengan yang berpendidikan rendah.

Ibu hamil yang pengetahuan tentang persalinannya kurang, mereka cenderung memiliki kesiapan persalinan yang kurang juga. Sedangkan bagi ibu hamil yang pengetahuan tentang persalinan baik, mereka cenderung memiliki kesiapan yang baik dalam menghadapi persalinan.

Kurangnya kesiapan ibu primigravida tentang persalinan dapat mengakibatkan ibu kesulitan dalam menghadapi persalinan seperti ibu kurang mengetahui tanda-tanda persalinan sehingga pada saat ada tanda persalinan ibu tidak segera datang ke bidan atau tenaga kesehatan. Kurangnya kesiapan ibu juga dapat mengakibatkan adanya istilah terlambat seperti yang dikemukakan oleh Prawirohardjo (2007) yaitu terlambat mengambil keputusan, terlambat membawa ketempat pelayanan kesehatan dan terlambatnya tenaga medis memberi pertolongan. Oleh karena itu, bidan dapat ikut berperan serta memberikan informasi yang jelas bagi ibu primigravida tentang persalinan dengan adanya pelayanan antenatal care yang baik selama kehamilan terutama pada ibu Primigravida yang akan menghadapi persalinan.

\section{KESIMPULAN}

1. Hampir sebagian Ibu Primigravida memiliki pengetahuan yang kurang tentang persalinan sebanyak 12 Ibu Primigravida (46,9\%).

2. Hampir seluruh Ibu Primigravida memiliki kesiapan yang kurang dalam menghadapi persalinan sebanyak 24 Ibu Primigravida $(85,7 \%)$.

3. Ada hubungan pengetahuan ibu primigravida dengan kesiapan ibu dalam menghadapi persalinan.

\section{REFERENSI}

Geniofam. (2010). 99 Tips Mempersiapkan Dan Menjaga Kehamilan. Leutika : Jakarta.

Gde, I.B., \& Manuaba. (2000). Ilmu Kebidanan, Penyakit Kandungan Dan Keluarga

Berencana Untuk Pendidikan Bidan. Arcan. Jakarta.

Latipun. (2001). Psikologi Konseling. Malang : UMM Press.

Manuaba, Gde, I.B., dkk. (2007). Pengantar Kuliah Obstetri. Jakarta : EGC. 
Mubarak. (2007). Promosi Kesehatan : Sebuah Pengamatan Proses Belajar Mengajar dalam Pendidikan. Yogyakarta : Graha Ilmu.

Notoatmodjo, S. (2005). Metodologi Penelitian Kesehatan. Rineka Cipta. Jakarta.

Nursalam. (2003). Konsep dan Penerapan Metodologi Penelitian Ilmu Keperawatan. Salemba Medika. Jakarta.

Prawirohardjo, W. (2007). Ilmu Kebidanan. Jakarta : YBP-SP.

Saleha, S. (2009). Asuhan Kebidanan Pada Masa Nifas. Jakarta : Salemba Medika 